\title{
生活圏アプローチのための概念モデリング手法
}

村田 秀則 ${ }^{* 1}$ ，小林 英樹*1

\section{Conceptual modeling method for living-sphere approach}

\author{
Hidenori MURATA $^{* 1}$ and Hideki KOBAYASHI ${ }^{* 1}$ \\ ${ }^{* 1}$ Graduate School of Engineering, Osaka University \\ 2-1 Yamadaoka, Suita-shi, Osaka 565-0871, Japan
}

Received: 18 October 2019; Revised: 20 February 2020; Accepted: 29 May 2020

\begin{abstract}
Ensuring sustainable consumption and production patterns is one of the United Nation's sustainable development goals (SDGs) for 2030. To achieve this, it is necessary for product development to consider not only reducing the environmental burden from a product life cycle but also satisfying human needs. The authors have proposed locally-oriented sustainable product design, which aims to improve the sufficiency of human needs and reduce the environmental impact by reflecting the regionally specific conditions in product development. For this purpose, a systematic approach for connecting fundamental human needs and the product development process, called the living-sphere approach, has been proposed. This approach uses a framework of fundamental human needs proposed by Max-Neef. The point of this approach is that product structures are connected to satisfiers. This study aims to propose a modeling method from a product to satisfiers in a living-sphere. In this study, we focus on reverse engineering and laddering method. By combining these bottom-up methods, we propose a modeling method from product structures to satisfiers. In a case study, we selected Japan as a target region and a rice cooker as an example. The result shows a possibility of this method for an evaluation of sufficiency, on the other hand, also shows the necessity of improvement of extracting regional requirements.
\end{abstract}

Keywords : Sustainable consumption and production, Living-sphere approach, Human scale development, Satisfier, Conceptual modeling, Laddering method, Reverse engineering, Systems modeling language

\section{1. 緒言}

持続可能な未来の実現に向け持続可能な開発目標 (SDGs: Sustainable Development Goals) が国連で採択された (UN, 2015). SDGs は貧困の根絶や地球の保護, すべての人が平和と豊かさを享受するための 17 の開発目標から なり, その一つに持続可能な消費と生産 (SCP: Sustainable Consumption and Production)の実現がある (UNEP, 2012). SCP の実現には資源消費量の削減や生活の質の向上が強く求められており, 生産者側だけでなく, 消費者側の充 足性を考慮したアプローチが必要とされている (梅田他, 2019)。一方で充足性は消費者の要求が地域によって大 きく異なるため，地域特有の条件 (地域性) を考慮した製品設計が必要とされている.

小林は地域特有の条件を製品仕様に反映することで地域住民の充足性向上と環境負荷低減を目指寸地域指向サ ステナブルデザインを提案している (Kobayashi, 2016).さらに，地域指向サステナブルデザインを実現するため のアプローチとして小林らは生活圈アプローチを提案している (Kobayashi and Fukushige, 2018). 生活圈アプロー チは対象地域の生活圈に着目し, 生活圈における住民の充足性を考慮した製品設計を行うためのアプローチであ る.本アプローチでは Max-Neef が提案する基本ニーズの枠組みを用いて地域住民の充足性を評価する (Max-Neef, 1991). Max-Neef の基本ニーズの枠組みは社会的普遍性をもつ基本ニーズと文化や経済状況などの地域性に依存 した充足手段であるサティスファイアからなる．本アプローチでは生活圈の充足性に寄与寸ると考えられる要素

\footnotetext{
No.19-00390 [DOI:10.1299/transjsme.19-00390], J-STAGE Advance Publication date : 8 June, 2020

*1 正員, 大阪大学 工学研究科（干565-0871 大阪府吹田市山田丘 2-1）

E-mail of corresponding author: murata@mech.eng.osaka-u.ac.jp
} 
(製品，サービス，自然環境など) に着目し，サティスファイアと製品群とを関係づけることで充足性を考慮した 製品設計を行う。一方でサティスファイアと製品群との関係づけを行う方法の確立が課題である.

本研究では生活圈アプローチの枠組みに基づいて充足性の観点から製品設計を行うために, 単一製品の構造・ 機能と基本ニーズの充足手段であるサティスファイアの概念関係をモデル化する手法を提案する．また，概念関 係のモデル化手法としては, サティスファイアから製品の機能・構造に向からトップダウンの方法と製品の構造・ 機能からサティスファイアに向からボトムアップの方法が考えられるが，本研究では既存製品の改良設計を行う ためにボトムアップのモデル化を試みる.

\section{2. 関連研究}

\section{$2 \cdot 1$ 製品設計とマーケティングに関する概念の整理}

工学設計では一般的に製品に対する要求から機能, 構造という順に展開し，トップダウンに設計の詳細化を行 $う$ (Paul and Beitz, 1988) (Ulrich and Eppinger, 1995). 例えば Function Structure Mapping (FSM) (Kmenta and Ishii, 1998) では, 機能と構造を扱い, Value Graph (VG) (石井, 飯野, 2008), Quality Function Deployment (QFD) (水野, 赤尾, 1978) (Hauser and Clausing, 1988) では，要求，機能，構造を扱う．また，Rosenman らは，設計で用いる概 念として, 目的 (Purpose), 機能, 振る舞い, 構造の 4 つを示している (Rosenman and Gero, 1998). 工学設計にお いては, 要求は一般的に顧客要求を意味する.

一方，システムズエンジニアリングでは，設計するシステム範囲を定義した後に要求分析を行い，アーキテク チャの設計を行う (Weilkiens, 2007) (INCOSE, 2015). 要求分析では, 利害関係者要求の抽出と要求詳細化を行う. アーキテクチャ設計では, 要求をもとに機能アーキテクチャの設計が行われ，ハードウェアとソフトウェアに機 能を割り当てる物理アーキテクチャの設計が行われる (西村, 藤倉, 2015)(INCOSE, 2015). システムがソフトウェ アのみで構成される場合は, 要求から直接物理アーキテクチャを設計する場合もある.

マーケティング分野では，消費者の意思決定行動のモデル化に手段-目的連鎖モデル (丸岡, 1996) (Reynolds and Olson, 2001) が用いられる. 手段-目的連鎖モデルにおける階層の定義は様々あるが，代表的なものの一つとして は製品の属性から消費者の機能的ベネフィット, 心理的ベネフィット, 価值観の 4 つの分類がある (Reynolds and Olson, 2001). ここでの属性とは製品の特徵を意味し, 機能的ベネフィットは使用によって得られる機能面の便益, 心理的ベネフィットは使用によって得られる心理面の便益, 価値観は消費者の持つ価值観を意味する. 自動車を 例とすると，「エアバッグ装備」という属性から「衝突しても安全」という機能的ベネフィット，「安心して運転 できる」という心理的ベネフィットが得られ，最終的に「家族を大事にしたい」という価值観につながる (丸岡, 1996).

これら工学設計, システムズエンジニアリング, マーケティングの各分野における概念を, Why, What, How という分類と対比させ整理すると図 1 のようになる．Why，What，How は製品設計においてそれぞれなぜその製 品が必要か, どのような製品 (価值) が必要か, どのようにして製品 (価值) を実現するのか, を意味する. 即ち, Why は製品の必要性，What は製品の機能，How は製品の実現構造を意味する.

\section{$2 \cdot 2$ 製品設計とマーケティングの概念関係分析手法}

本節では構造から機能, 要求, サティスファイアへの関係づけを行うため, ボトムアップの概念関係分析手法 に関連するレビューを行う.

構造や機能の分析を行う方法としてリバースエンジニアリング (Otto and Wood, 2000) (佐藤, 1997) が知られて いる. リバースエンジニアリングでは 1. 市場調査により要求を調査, 2. その市場の代表的な製品を分析, 分解 することで対象製品の構造や振舞いを抽出, 3. これらの情報をもとにした機能分析, という3つの手順によって 機能を抽出する. Otto らは機能分析に使用する手法として, The Functional Analysis System Technique (FAST) や The Subtract and Operate Procedure が有効であると述べている (Otto and Wood, 2000).

工学設計における構造, 機能, 要求の分析支援手法としてVG(石井, 飯野, 2008)が挙げられる.VG は対象製品 の目的，要求，機能，構造を抽出および可視化する方法である.VG では要求分析を繰り返すことで製品の目的 が抽出される，つまり，なぜそれが必要か (Why) を尋ねることで構造から機能, 要求から目的を抽出し, どう 


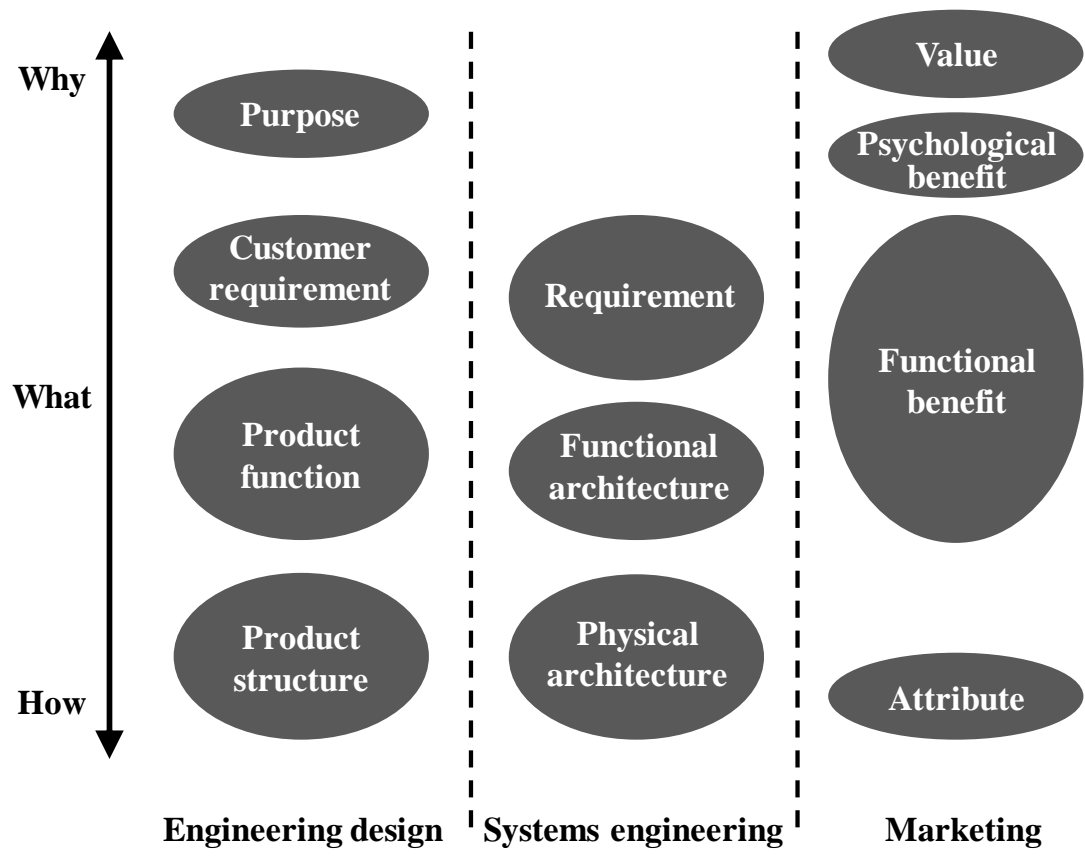

Fig. 1 Concept classification by Why, What and How.

やって実現するか (How) を尋ねることで目的から要求，機能から構造を抽出する，一般的に VG では対象製品 を中心に配置し，その上部に製品に対する要求と目的 (Why) を，下部に機能 (What) と構造(How) を示すこと で，対象製品の目的，要求，構造，機能を図示する.

マーケティング分野では消費者の潜在的ニーズを探る手法としてラダリング法 (Gutman, 1982) (丸岡, 1996) (Reynolds and Olson, 2001) が提案されている. ラダリング法はインタビュー方式で行われ，まず消費者に対し， 対象製品と他社の同種製品を比較してなぜ対象製品を好むのかという質問を行う。これにより差異となる属性を 抽出する. 次に，その属性が消費者にとってなぜ重要かという質問を繰り返すことで属性から消費者が得る機能 的ベネフィット, 心理的ベネフィットさらには消費者の価值観を明らかにする.このように明らかにされた属性, ベネフィット，価值観の階層構造を手段-目的連鎖モデルと呼ぶ (Reynolds and Olson, 2001). ただし，本手法はイ ンタビュー方式に基づくため, 手段-目的連鎖モデルの質はインタビュワーの技量やインタビュー方法に大きく依 存する (Reynolds and Olson, 2001) (Holtzclaw, 2013).

工学設計分野では How から What まで部分的に関係づける手法はあるが，一気通貫で関係づける手法はなく， 対象も製品のみである。一方でラダリング法は製品属性からべネフィットを介し価值観まで一気通貫で関係づけ られるが，あくまでも消費者視点での分析であり，実際の製品の構造，機能を参照していないため，製品分析に そのまま用いることは難しい.

\section{3. 提案手法}

本論文では生活圏アプローチの枠組みに基づいて製品の構造・機能と基本ニーズの充足手段であるサティス ファイアの概念関係をモデル化する手法を提案する. 以下ではまず本研究の基礎理論である地域指向サステナブ ルデザインに関して述べる.

\section{$3 \cdot 1$ 地域指向サステナブルデザイン}

持続可能な消費と生産の実現には生産者側の環境負荷の低減と消費者の充足性の向上が求められている.これ までに生産者側では，ライフサイクル設計に関する方法論の構築と適用が行われてきた (Kobayashi et al., 2005) (Umeda et al., 2012). 一方で充足性に関しては，国連開発計画が提案する人間開発指数や経済協力開発機構が提案 する主観的幸福度など，国レベルの充足度評価は行われているが，これらの指標を製品設計に適用することは難 しい (UNDP, 2015) (OECD, 2013). 小林は地域特有の条件 (地域性) を考慮し，環境性と充足性を両立した製品設 
計手法として地域指向サステナブルデザインを提案している(Kobayashi, 2016). 本手法は地域性を考慮した製品設 計手法として拡張機能-構造図 (EFSM: Extended Function-Structure Mapping) と，フィールドスタディや現地製品 のリバースエンジニアリングを組み合わせることで地域向け製品設計を行う EFSA (Extended Function-Structure Analysis) を提案している (Sugita et al., 2017).

また小林らは地域指向サステナブルデザインを行うためのアプローチの一つとして, 生活圈アプローチを提案 している (Kobayashi and Fukushige, 2018). 図 2 に生活圈アプローチのフレームワークを示す. 本アプローチは, 対象地域の生活圈に着目し, 生活圈における住民の充足性を考慮した製品設計を行うためのアプローチである. ここでの生活圈とは住民の日常生活で行動する範囲を意味し, 家庭や職場を含む. 本アプローチの特徵は, MaxNeef が提案する基本ニーズの枠組みを用いて生活圈住民の充足性を捉えようとしている点にある. Max-Neef は, 人間が満たすべきニーズを 9 種類の基本ニーズ (生存, 保護, 愛情, 理解, 参加, 無為, 創造, アイデンティティ, 自由) と 4 種類の存在形式 (状態, 所有, 行動, 環境) に分類しており, これらは文化, 地域には依存せず社会的 普遍性を持つと述べている (Max-Neef, 1991). この基本ニーズの充足手段としてサティスファイアが提案されて いる. サティスファイアは地域，時代，年齢など対象とする人々やその集団により変化するものであり，サティ スファイアを実現することが基本ニーズの充足につながるとされている. サティスファイアはサティスファクタ (Kamenetzky, 1981) と同様の概念である.

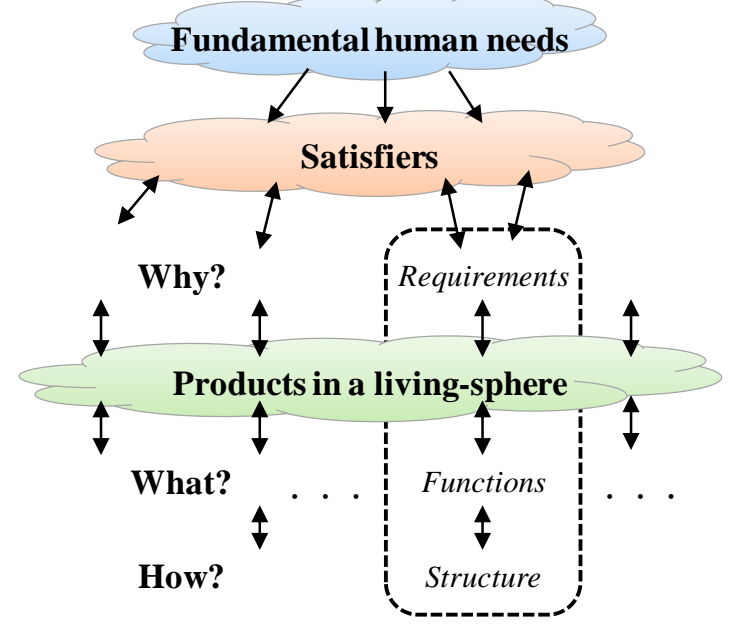

Fig. 2 Framework of the living-sphere approach.

表 1 に基本ニーズとその充足手段であるサティスファイアのマトリクス例を示す (Max-Neef, 1991). サティス ファイアは 9 種類の基本ニーズと 4 種類の存在形式からなるマトリクスの各セルに存在し， ワークショップ法に より抽出される(Guillen-Royo, 2015) (Kobayashi et al., 2019). ワークショップ法では 4-6 人を 1 グループとし, 表 1 の各セルを満たすサティスファイアをディスカッションにより抽出する. 表 1 の例では, 生存 (Subsistence) の状 態 (Being) を満たすサティスファイアとして身体的健康 (Physical health)や精神的健康 (Mental health) が抽出さ れている. 生活圈アプローチは対象地域のサティスファイアを満たすために, 生活圈製品のどのような構造, 機 能が充足性に大きく関わっているかを明確化することで，対象地域向けの製品設計を行うアプローチである.

サティスファイアの分析を行った研究として Guillen-Royo の研究がある(Guillen-Royo, 2015). Guillen-Royo ら はスペインのグラナダにおいてワークショップを行い, サティスファイアの抽出および抽出されたサティスファ イアの分析を行っている. また Max-Neef の基本ニーズの枠組みを応用した研究として, Vita らの研究が挙げら れる (Vita et al., 2019). Vita らは産業連関表を用い, 各産業分野における基本ニーズごとの $\mathrm{CO}_{2}$ 排出量を算出して いる.しかし，これらの研究では Max-Neefの基本ニーズの枠組みの製品設計への適用は行われていない. 
Table 1 An example of a matrix of fundamental human needs and satisfiers.

\begin{tabular}{|c||l|l|l|l|}
\hline $\begin{array}{c}\text { Needs according } \\
\text { Needs to existential } \\
\text { according categories } \\
\text { to axiological } \\
\text { categories }\end{array}$ & \multicolumn{1}{|c|}{ Being } & Having & Doing & Interacting \\
\hline \hline Subsistence & $\begin{array}{l}\text { Physical health, } \\
\text { Mental health }\end{array}$ & $\begin{array}{l}\text { Food, shelter, } \\
\text { work }\end{array}$ & $\begin{array}{l}\text { Feed, procreate, } \\
\text { Rest, work }\end{array}$ & $\begin{array}{l}\text { Living } \\
\text { environment }\end{array}$ \\
\hline Protection & $\begin{array}{l}\text { Care, autonomy, } \\
\text { adaptability }\end{array}$ & $\begin{array}{l}\text { Insurance } \\
\text { systems, savings }\end{array}$ & $\begin{array}{l}\text { Cooperate, plan, } \\
\text { prevent }\end{array}$ & $\begin{array}{l}\text { Living space, } \\
\text { dwelling }\end{array}$ \\
\hline Affection & $\begin{array}{l}\text { Self-esteem, } \\
\text { solidarity }\end{array}$ & $\begin{array}{l}\text { Friendships, } \\
\text { family }\end{array}$ & $\begin{array}{l}\text { Make love, } \\
\text { caress }\end{array}$ & $\begin{array}{l}\text { Privacy, home, } \\
\text { intimacy }\end{array}$ \\
\hline Participation & $\begin{array}{l}\text { Adaptability, } \\
\text { Respect, passion }\end{array}$ & $\begin{array}{l}\text { Rights, duties, } \\
\text { privileges }\end{array}$ & $\begin{array}{l}\text { Propose, share, } \\
\text { dissent, obey }\end{array}$ & $\begin{array}{l}\text { Associations, } \\
\text { churches }\end{array}$ \\
\hline Idleness & $\begin{array}{l}\text { Curiosity, sense } \\
\text { of humour }\end{array}$ & $\begin{array}{l}\text { Games, clubs, } \\
\text { parties }\end{array}$ & $\begin{array}{l}\text { Day-dream, } \\
\text { brood, dream }\end{array}$ & $\begin{array}{l}\text { Privacy, free } \\
\text { time, intimacy }\end{array}$ \\
\hline Creation & $\begin{array}{l}\text { Passion, } \\
\text { determination }\end{array}$ & $\begin{array}{l}\text { Abilities, skills. } \\
\text { method, work }\end{array}$ & $\begin{array}{l}\text { Work, invent, } \\
\text { build, design }\end{array}$ & $\begin{array}{l}\text { Cultural groups, } \\
\text { audiences }\end{array}$ \\
\hline Identity & $\begin{array}{l}\text { Sense of } \\
\text { belonging }\end{array}$ & $\begin{array}{l}\text { Symbols, habits, } \\
\text { language, norms }\end{array}$ & $\begin{array}{l}\text { Commit oneself, } \\
\text { confront, grow }\end{array}$ & $\begin{array}{l}\text { Everybody } \\
\text { settings }\end{array}$ \\
\hline Freedom & $\begin{array}{l}\text { Autonomy, } \\
\text { passion }\end{array}$ & Equal rights & $\begin{array}{l}\text { Dissent, choose, } \\
\text { run risks }\end{array}$ & $\begin{array}{l}\text { Temporal/spatial } \\
\text { plasticity }\end{array}$ \\
\hline
\end{tabular}

\section{$3 \cdot 2$ 製品とサティスファイアの概念関係モデル化手法}

本研究では $2 \cdot 2$ 節で述べたボトムアップ概念関係分析手法を組み合わせることで, 単一製品からサティスファ イアまで一貫してボトムアップに概念関係をモデル化する手法の提案を行う. 図 3 に提案手法の手順を示す. 本 手法は対象製品の設計者および分析者が充足性を考慮した製品の改良設計を行う際に利用することを想定する. 生活圏アプローチにおいてサティスファイアは地域における基本ニーズの充足手段であり，表 1 に示すように抽 象度が高く，サティスファイアと製品とを直接関係づけることは難しいと考えられる．そのため本研究では，顧 客要求より抽象度の高い地域に関する要求 (地域要求) を新たに定義し, 地域要求とサティスファイアの関係づ けを試みる。地域要求とは対象地域における住民の要求である。しかし，地域要求をすべて抽出することはその 膨大さと地域の認識の違いにより困難である. 本手法では対象製品が満たしていると考えられる地域要求のみに 注目し，抽出を行う。また提案手法においてサティスファイアは 3.1 で述べたワークショップ法を用いて既に抽 出されていることを前提とする. 以下では, 図 3 の各ステップの詳細を述べる.

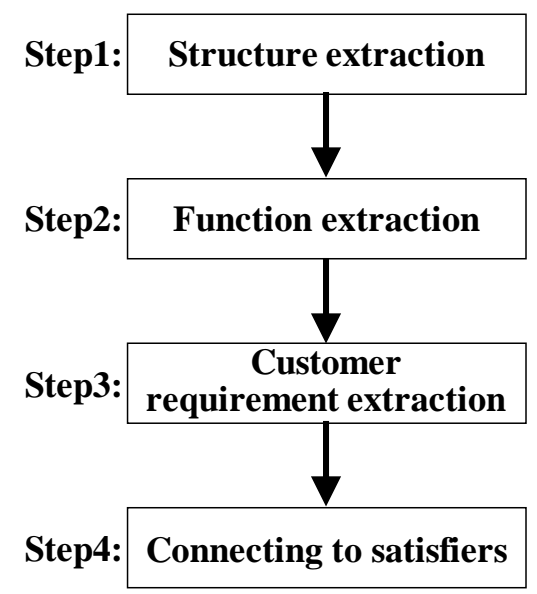

Fig. 3 Proposal method of conceptual modeling from product structures to satisfiers. 
Step1: 構造抽出

構造抽出はテアダウンを用いて行う．テアダウンはリバースエンジニアリングの手法の一つであり, 複数製品 の分解による比較分析に用いられる (佐藤, 1997). 本研究ではテアダウンを対象製品の構造抽出に用い, 製品を 構成する部品を明らかにする．ただし，構造情報がすでに存在する場合，本ステップを行う必要はない.

Step2: 機能抽出

機能抽出ではまず，Step1 で抽出された部品群に対し，機能分析を行うことでそれぞれが満たす機能を抽出す る．その後 VG を用い，なぜその機能が実行されるのか，あるいはなぜその機能が必要か，という質問を対象製 品の設計者に対し繰り返すことで上位機能を抽出, 機能階層を作成する.

Step3: 顧客要求抽出

顧客要求抽出では製品に対する顧客要求の抽出を目的とし，ラダリング法を応用することで抽出を行う．ラダ リング法では製品の属性から消費者にとっての機能的ベネフィットや心理的ベネフィットを抽出する. しかしこ こではあくまでも対象製品の機能がどのような顧客要求を実現しているかを抽出したいため，対象を消費者から 設計者あるいは分析者に変更し，各機能に対しなぜその機能が製品にとって重要か，という質問を対象製品の設 計者あるいは分析者に対し繰り返すことで製品の顧客要求を抽出する.

Step4: サティスファイアとの関係づけ

本ステップでは顧客要求から地域要求を抽出し, その後にサティスファイアとの関係づけを行う。地域要求は 地域住民の要求であるため, 本ステップでは設計者あるいは分析者と対象地域の複数の住民で抽出を行う．抽出 を行う住民の人数に関しては, サティスファイアの抽出と同等の人数 (4-6 人) で行うことを想定する. 地域要求 は, Step3 で抽出された顧客要求にラダリング法を適用し, なぜその要求が地域で必要か, その要求はあなたに とって地域においてなぜ重要か，という質問を対象地域の住民らに対し繰り返すことで抽出を行う．抽出された 地域要求はサティスファイアと一対比較を行い, サティスファイアを満たす場合はその地域要求とサティスファ イアを関係づける. 地域要求がサティスファイアを満たすかの判断は, 対象地域の住民らとのディスカッション で行い，過半数が満たすと判断する場合，サティスファイアと地域要求を関係づける.

図 4 に本手法を用いたモデル化の概略図および各要素間の関係 (矢印) の定義を示す. 本モデル化では, シス テムモデリングを参考に構造, 機能, 顧客要求, 地域要求, サティスファイアの各要素間の関係を定義した (Weilkiens, 2007) (西村, 藤倉, 2015).「part of」は接続元が接続先の一部であることを，「allocate」は接続元の構造 が接続先の機能に割り当てられていることを,「satisfy」は接続元の機能が接続先の顧客要求を実現していること を,「derive」は接続元の顧客要求や地域要求が接続先の顧客要求や地域要求と導出関係にあることを,「associate」 は地域要求とサティスファイアが関連していることを意味している.

\section{4. ケーススタディ}

\section{$4 \cdot 1$ 対象地域と製品}

本ケーススタディでは提案手法に従い製品とサティスファイアの概念関係モデル化を試みた。対象地域は大阪 とし, サティスファイアの抽出対象としては都市中間層の学生と若者 (20-40歳の社会人) とした. 対象製品とし ては日本の一般家庭に広く普及している製品の一つである炊飯器を選定した．対象とする炊飯器は 2015 年製の IH (Induction Heating) 式で，容量は 5.5 合のものとした.

\section{$4 \cdot 2$ 製品とサティスファイアの概念関係モデル化結果}

以下では 3 章で提案した概念関係モデル化手法に従い, 日本製炊飯器と日本のサティスファイアのモデル化を 行った結果を述べる. 本ケーススタディでは，サティスファイアとして共通サティスファイアを用いた．共通サ 


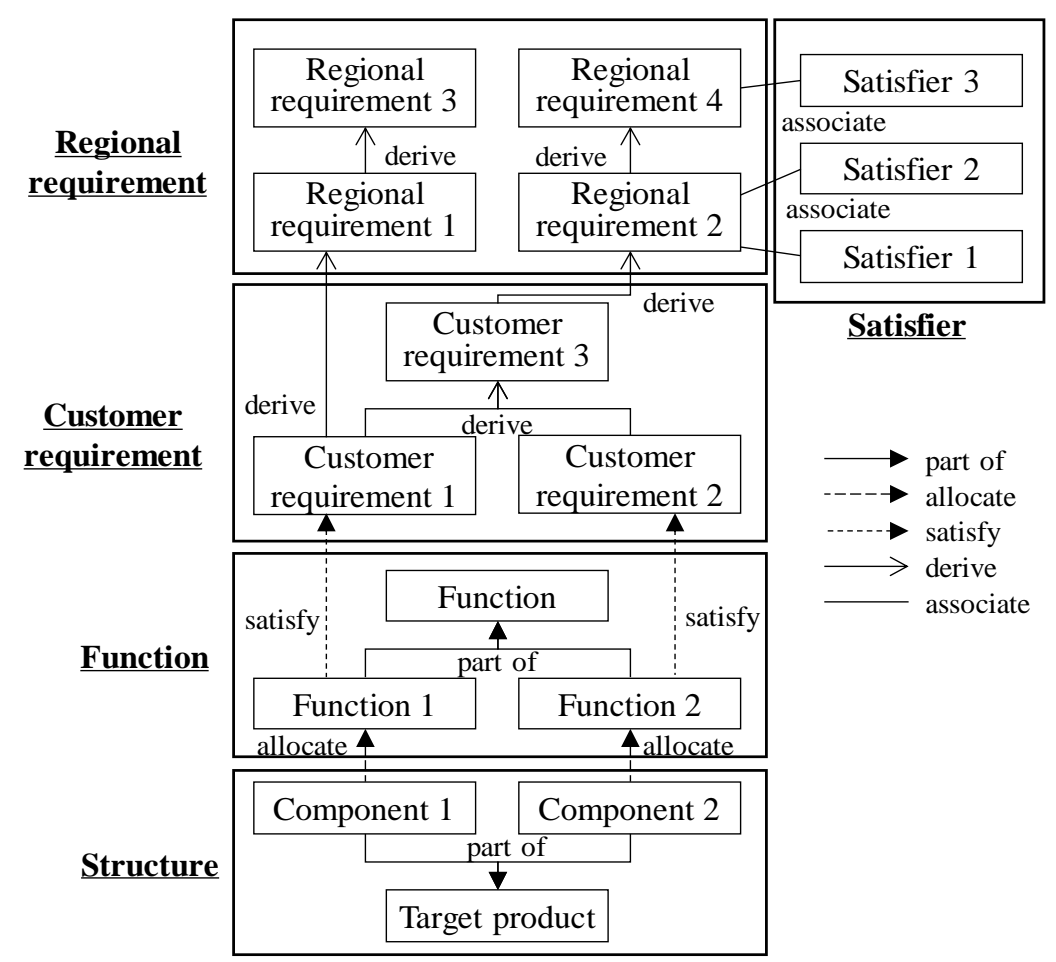

Fig. 4 A conceptual model from product structures to satisfiers.

ティスファイアとは, 対象地域の都市中間層の学生, 若者から得られたサティスファイア(Sumimura et al., 2018)の うち, 学生, 若者の両方で抽出されたサティスファイアを意味する. 表 2 にワークショップで抽出された 91 個の 共通サティスファイアを示す.

本ケーススタディでは，構造からサティスファイアのモデル実装に Systems Modeling Language (SysML) (Friedenthal et al.,2012) を用いた. SysML はシステムズエンジニアリング分野で用いられるハードウェア, ソフト ウェアを含むシステムを表現するためのモデリング言語であり, システムの要求，振る舞い，機能，構造を表現 寸ることが可能である. 図 5 に SysML の構成を示す. 本研究では SysML に拡張プロファイルを追加することで, システムの要求，機能，構造だけでなく地域要求，サティスファイアを表現できるようにした．以下では 3 章の 手順に従いモデル化を行った結果を示す.

\section{Step1: 構造抽出}

本ステップでは，杉田らの同製品に対するテアダウン結果と構造図 (Sugita et al., 2017) を参考に，構造抽出を 行った. その結果, 39 個の部品からなる構造ツリーを作成した. 図6では, 抽出された部品のうち, 炊飯に関す る 10 個の部品からなる構造ツリーを示している. 構造は SysML のブロック定義図を用いて表記を行った.

Step2: 機能抽出

構造抽出で得られた 39 個の要素から機能抽出を行った結果，計 12 個の下位機能が抽出され，それらをもとに 19 個の機能からなる機能図を作成した. 図 7 では抽出された機能のうち, 炊飯に関する 9 個の機能および各機能 の抽出元の部品を示している．機能も構造と同様，SysML のブロック定義図を用いて表記を行った.

Step3: 顧客要求抽出

機能抽出で抽出された 19 個の機能からラダリング法を用いた結果, 自動炊飯, マルチ調理, 自動保温, 使いや すさ, 長寿命の計 5 つのカテゴリの顧客要求が作成された. 抽出された顧客要求数は, 自動炊飯が 10 個, マルチ 調理が 7 個, 自動保温が 14 個, 使いや寸さが 6 個, 長寿命が 14 個であった. 図 8 では自動炊飯に関連する顧客 要求および顧客要求の抽出元の機能を示している. ここで, 顧客要求はSysML の要求図を用いて表記した. 
Table 2 Matrix of fundamental human needs and common satisfiers.

\begin{tabular}{|c|c|c|c|c|}
\hline & Being & Having & Doing & Inte racting \\
\hline Subsistence & $\begin{array}{ll}\checkmark & \text { Healthy } \\
\checkmark & \text { Accesible to food } \\
\checkmark & \text { Usual }\end{array}$ & $\begin{array}{ll}\checkmark & \text { Money } \\
\checkmark & \text { Food } \\
& \text { House }\end{array}$ & \begin{tabular}{|ll}
$\checkmark$ & Eating \\
$\checkmark$ & Sleeping \\
$\checkmark$ & Talking
\end{tabular} & $\begin{array}{l}\text { Access to water } \\
\text { Avilability of electricity } \\
\text { Filled with air } \\
\text { Comfortable temperature } \\
\checkmark \text { Friends and family } \\
\end{array}$ \\
\hline Protection & $\begin{array}{l}\text { Home } \\
\text { Loved }\end{array}$ & N/A & $\checkmark$ Acting with compassion & Space for living \\
\hline Affection & $\begin{array}{ll}\checkmark & \text { Happy } \\
\checkmark & \text { With someone reliable }\end{array}$ & $\begin{array}{l}\text { Someone precious } \\
\checkmark \text { Kindness }\end{array}$ & 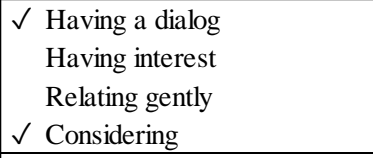 & N/A \\
\hline Understanding & \begin{tabular}{|ll}
$\checkmark$ & Communicatable \\
$\checkmark$ & Talkable \\
$\checkmark$ & Describable \\
& Logical \\
$\checkmark$ & Sympathetic \\
$\checkmark$ & Understandable \\
\end{tabular} & $\begin{array}{l}\checkmark \text { Knowledge } \\
\checkmark \text { Comprehension }\end{array}$ & $\begin{array}{ll}\checkmark & \text { Communicating } \\
\checkmark & \text { Educating } \\
& \text { Having interest }\end{array}$ & $\begin{array}{l}\checkmark \text { Opportunity for discussion } \\
\checkmark \text { Opportunity to gain knowledge } \\
\checkmark \text { Using same language } \\
\checkmark \text { Something to learn } \\
\quad \text { SNS }\end{array}$ \\
\hline Participation & $\checkmark$ Belongs & $\begin{array}{l}\checkmark \text { Specific knowledge } \\
\text { Shared goal }\end{array}$ & \begin{tabular}{|l} 
Promoting \\
$\checkmark$ \\
Keeping in touch \\
Having aggressive mind \\
Participating in a community
\end{tabular} & $\begin{array}{l}\checkmark \text { Same kind of people } \\
\checkmark \text { Means of communication } \\
\checkmark \text { Right to voice }\end{array}$ \\
\hline Idleness & \begin{tabular}{|l} 
Lazy \\
$\checkmark$ Relaxed
\end{tabular} & $\begin{array}{l}\checkmark \text { Free time } \\
\text { Comfortable space } \\
\checkmark \text { Freedom }\end{array}$ & $\begin{array}{ll}\checkmark & \text { Lying } \\
\checkmark & \text { Taking a rest }\end{array}$ & $\begin{aligned} \checkmark & \text { No obstraction } \\
& \text { No restriction } \\
\checkmark & \text { Safety space }\end{aligned}$ \\
\hline Creation & \begin{tabular}{|ll}
\multicolumn{1}{|c}{ Critical } \\
$\checkmark$ & Composure \\
$\checkmark$ & Free \\
& Creativity
\end{tabular} & $\begin{aligned} & \checkmark \text { Knowledge } \\
& \text { Skill } \\
& \checkmark \text { Material } \\
& \text { Means to express } \\
& \text { Purpose } \\
&\end{aligned}$ & $\begin{array}{l}\checkmark \text { Collecting information } \\
\text { Preparing } \\
\text { Challenging }\end{array}$ & $\begin{array}{l}\checkmark \checkmark \text { Chance to be criticized } \\
\checkmark \text { No restriction } \\
\checkmark \text { Interacting with others } \\
\checkmark \text { Existence of supporters }\end{array}$ \\
\hline Identity & $\checkmark$ Acknowledged & $\checkmark$ Accepted feeling & \begin{tabular}{|l}
$\checkmark$ Acknowledging \\
Enthusing \\
$\checkmark$ Comparing \\
\end{tabular} & $\begin{array}{l}\checkmark \text { Chance to be acknowledged } \\
\text { No restriction } \\
\text { Free will } \\
\end{array}$ \\
\hline Freedom & Leisure & N/A & $\checkmark$ Doing what I want & $\begin{array}{l}\text { Bias free } \\
\text { Peaceful world } \\
\text { Respect for human rights }\end{array}$ \\
\hline
\end{tabular}

$\checkmark$ Satisfiers satisfied by Japanese rice cooker

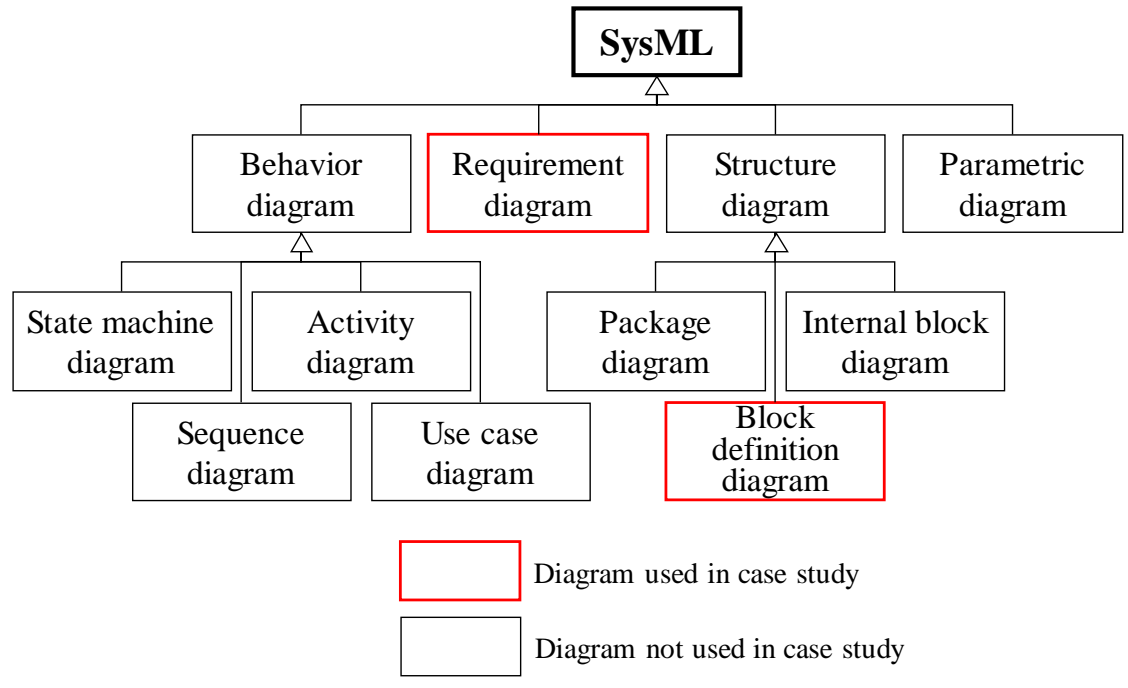

Fig. 5 SysML diagrams. 




Fig. 6 Modeling result of structure for a Japanese rice cocker.

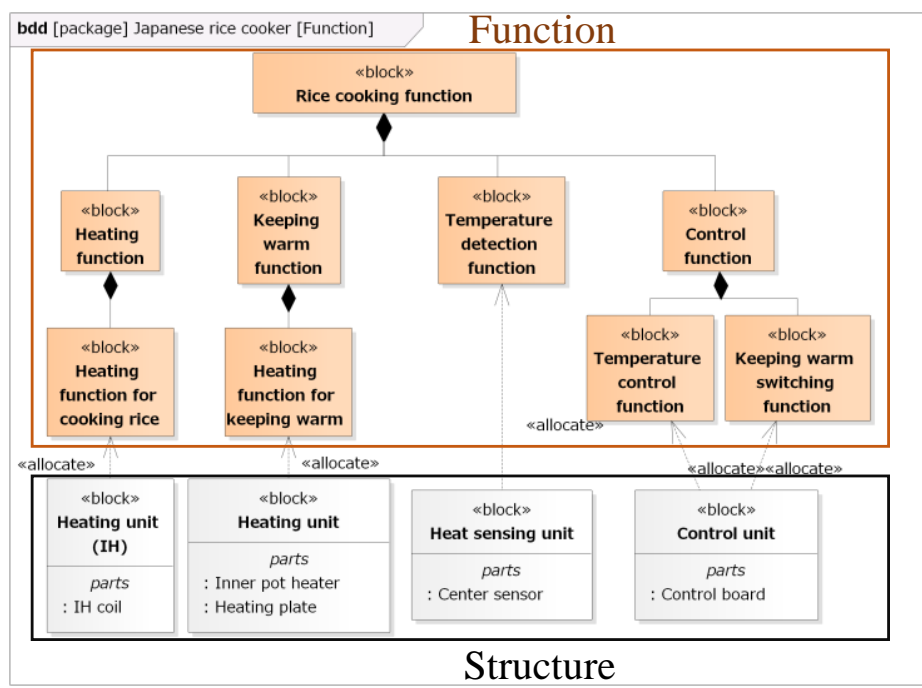

Fig. 7 Modeling result of function for a Japanese rice cocker.

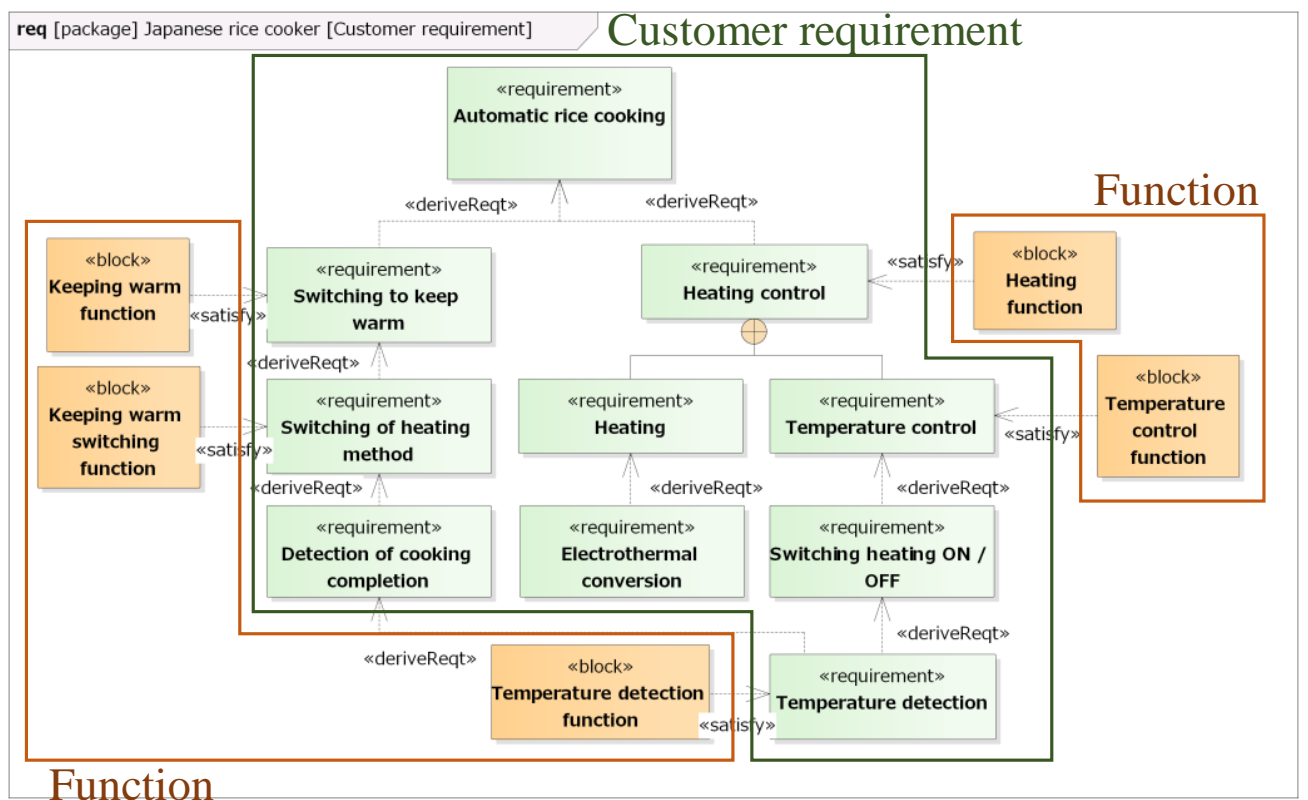

Fig. 8 Modeling result of customer requirement for a Japanese rice cocker. 
Step4: サティスファイアとの関係づけ

本ステップでは，大阪の複数の大学生を対象にラダリング法を用いることで地域要求を抽出した。 また，抽出 した地域要求を対象の学生が再度確認することで検証を行った，その結果，自動炊飯のカテゴリからは 57 個，マ ルチ調理からは 57 個, 自動保温からは 31 個, 使いやすさからは 8 個, 長寿命からは 22 個の地域要求が抽出さ れた. また 91 個の共通サティスファイアのうち，56 個が日本製炊飯器の地域要求と関係づけられた。図 9 では 自動炊飯から抽出された地域要求とそれらと関係づけられたサティスファイアの一部を示している. 地域要求に 関しては, システムバウンダリがこれまでの製品ではなく地域に拡張されるため, Step3で用いた要求図とは異な る要求図に表記を行った.

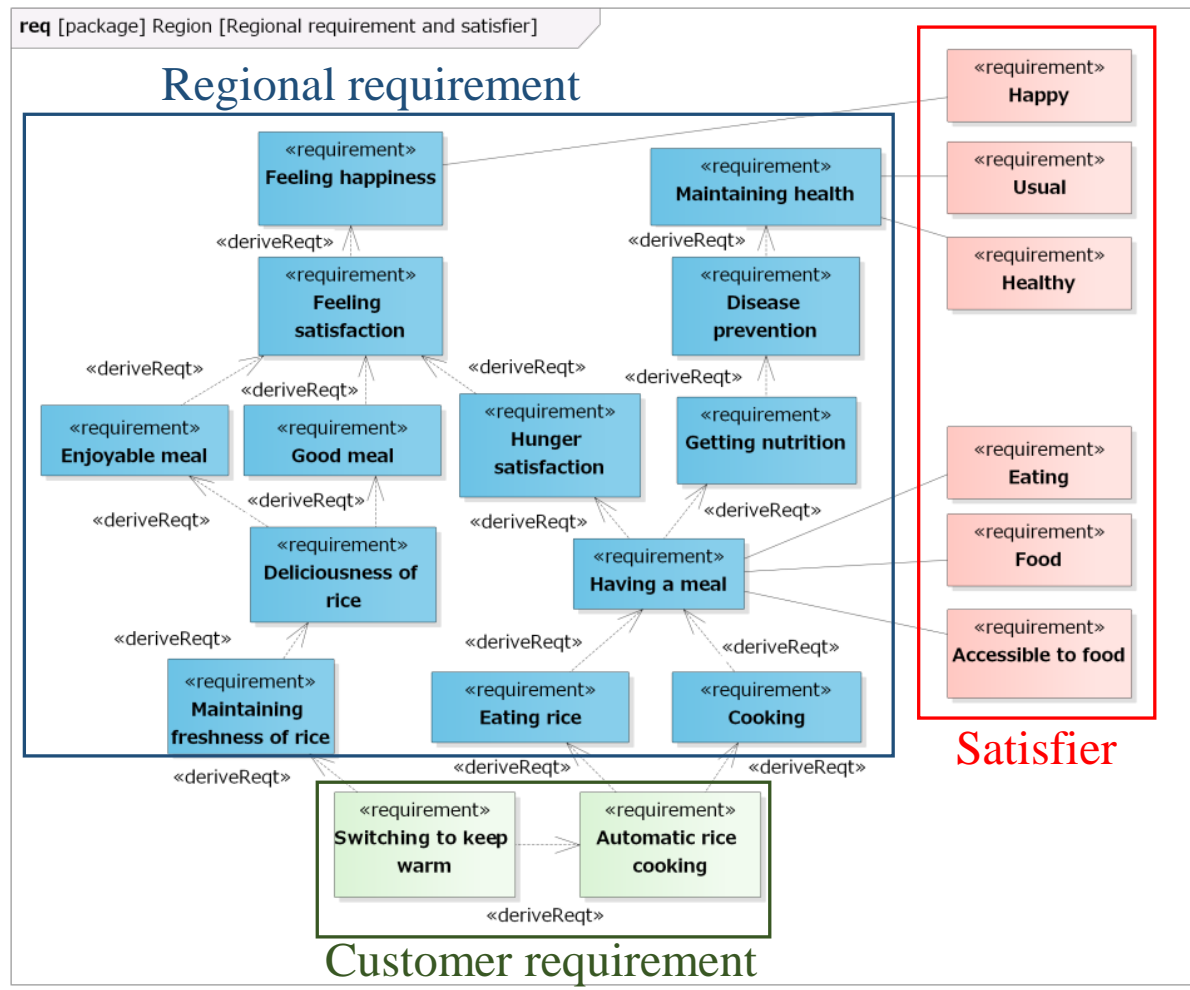

Fig. 9 Modeling result of regional requirement and satisfier.

上記の結果を以下で考察する. 日本製炊飯器のモデル化結果より 91 個の共通サティスファイアのうち 56 個が 日本製炊飯器と関係づけられることが分かった。一方で，サティスファイアは地域における基本ニーズの充足手 段であり，充足手段には製品だけでなくサービスや自然環境など様々な要素が存在する.今回関係づけられたサ ティスファイアを炊飯器が充足するサティスファイアと捉えたならば，高々一つの製品である炊飯器の結果とし ては充足されるサティスファイアの数が過剰である可能性を示唆している.

地域要求とサティスファイアとの関係づけをさらに分析するため, 本研究ではラダ一階層を定義し, 分析を行っ た. ラダ一階層とは, 地域要求が顧客要求から何回質問を繰り返したものであるかを表しており, 複数の数值を 持つ場合は最小值を採用した。 また，共通サティスファイアが複数の地域要求と関係づけられる場合は最小のラ ダー階層を採用した。図 10 に炊飯器により充足される 56 個のサティスファイアがどのラダー階層の地域要求と 関係づけられるかで分類した結果を示す. 分類結果より, ラダー階層が 4 の共通サティスファイア数が最大であ ることがわかる．これはラダー階層，即ちラダリング法による質問回数を変更することで関係づけられるサティ スファイアの数を制御できる可能性を示唆しており, 目的に合わせたラダ一階層を予め決めておくことで過剰な 関係づけを防げる可能性がある. 一方でラダー階層は地域要求の抽出方法に依存しているため, ラダリング法の 参加人数や参加者のプロフィール，インタビュー方法により大きく変わる可能性がある. 


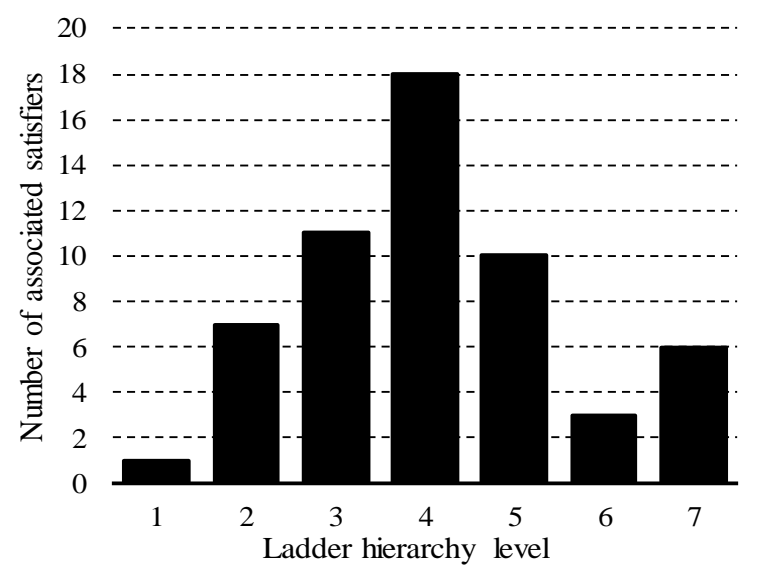

Fig. 10 Number of connected satisfiers classified by ladder hierarchy level. This graph shows that 1 , $7,11,18,10,3$ and 6 satisfiers are connected to ladder hierarchy levels 1, 2, 3, 4, 5, 6 and 7 respectively.

\section{5. 考察と展望}

\section{$5 \cdot 1$ 考察}

本手法では製品に対する要求と地域における住民の要求を異なるものとして捉え，前者を顧客要求，後者を地 域要求と定義した，今回のケーススタディにおいては，顧客要求として「自動炊飯」などが，一方で地域要求と して「食事の摂取」「健康の維持」などが抽出された。この結果から, 下位の地域要求は顧客要求と類似している ものもあるが，上位の地域要求と顧客要求とは抽象度が異なっていることがわかる．特に「食事」「食べ物」や 「健康な」といったサティスファイアとの関係づけを行う際に地域要求が効果的に働いていることがわかる．こ の結果から地域要求を用いた概念関係のモデル化は有効であると考えられる。一方で，地域要求とサティスファ イアがほぼ同一の意味を表している場合があり, どの程度の抽象度までを地域要求とするかは今後の課題である. また，今回の関係づけが地域要求によるサティスファイアの充足を意味するか否かについては今後の分析が必要 である.

個人の生活を考慮した製品設計手法としてペルソナ法がある (Pruitt and Grudin, 2003). ペルソナ法は仮想の人 物像を用いた製品設計手法であり，ターゲットユーザの代表的な属性を持つペルソナを作成し，設計チームでペ ルソナの理解を共有することでユーザ指向の製品設計を行う。しかし，ペルソナ法は基本ニーズの充足性を陽に 意識していない。これに対し，本研究では複数の地域住民から抽出したサティスファイアを用いて地域性と充足 性の双方を考慮した製品設計を目指寸ものである.

本ケーススタディでは概念関係のモデル化に SysML を用いたことで, 構造から顧客要求の抽出までは可視性 やトレーサビリティの高いモデリングを行うことができた．これはシステムバウンダリとステークホルダが明確 に定義できるからである. 一方で地域要求は，ラダリング法の対象者の生活経験に依存して結果が変化する可能 性がある。こうした特徵を持つ地域要求のモデル化は今後さらなる検討が求められる.

今回はリバースエンジニアリングの対象を機械部品のみとしたが，リバースエンジニアリングでは電子回路や ソフトウェアなど機械部品以外の製品構成要素の機能分析 (Function analysis) も可能である.また本手法におい て実装に用いた SysML は, オブジェクト指向モデリング言語であるため, 電気回路, ソフトウェアを機械部品と 同椂にブロック定義図を用いて定義可能である. そのため機械部品以外に関しても本手法による関係性モデル化 が可能である.ただし，一般的に設計において時間，コストと精度はトレードオフ関係であり，また分析やモデ リングは設計者の能力に依存する. そのためどの程度まで分析を行うかはその時の条件に合わせて決める必要が ある. 


\section{$5 \cdot 2$ 展望}

提案手法により製品からサティスファイアまでの概念関係を明らかにすることができた．これにより，どの製 品の構造や機能がサティスファイアの充足, 即ち基本ニーズの充足に寄与しているかの分析や, さらにその結果 をもとに対象地域における基本ニーズ充足設計への展開に応用できる可能性がある.

本研究では構造からサティスファイアへのボトムアップの概念関係モデル化を試みたが，トップダウンのモデ ル化やその他の方法も試行することで，対象地域向けの製品設計により適した概念関係モデル化手法を明らかに していくことが求められる．特に生活圈は製品群から構成されることがほとんどであるため，本手法を製品群に 展開していく必要がある. また，生活圈におけるサティスファイアの充足手段は製品以外にも存在すると考えら れる．そのため製品の夕ならずサービスや自然環境を含めた概念関係のモデル化手法を構築する必要がある.

\section{6. 結 言}

地域指向サステナブルデザインの実現に向け，ボトムアップ概念関係分析手法を連携させることで生活圈アプ ローチに基づいた単一製品とサティスファイアの概念関係モデル化手法を提案した. 本モデル化では製品構造・ 機能から対象地域住民の要求である地域要求を介し, サティスファイアと関係づけを行うことが特徴の一つであ る.

ケーススタディでは，汎用図的モデリング言語 SysML を用いて大阪の都市中間層のサティスファイアと日本 製炊飯器との概念関係モデル化を行った．その結果，ボトムアップのモデル化では製品とサティスファイアが過 剩に関係づけられる可能性があること, 地域要求とサティスファイアの関係づけを分析することで過剩な関係づ けが防げる可能性があることを見出した．今後の展望は関係づけの強度を考慮した充足度評価や過剩な関係づけ への対策，生活圈の製品群による評価が挙げられる.

\section{謝 辞}

本研究は, (独) 環境再生保全機構の環境研究総合推進費 (S-16) により実施されました.また, 本研究に協力 いただいた大阪大学工学部応用理工学科 (当時) の岡崎祐樹氏に感謝いたします.

\section{文献}

Friedenthal, S., Moore, A. and Steiner, R., A Practical Guide to SysML (2012), Morgan Kaufmann.

Guillen-Royo, M., Sustainability and Wellbeing: Human-Scale Development in Practice (2015), Routledge.

Gutman, J., A Means-End chain model based on consumer categorization processes, Journal of Marketing, Vol.46, No.2 (1982), pp.60-72.

Hauser, J. and Clausing, D., The house of quality, Harvard Business Review, Vol.66, No.3 (1988), pp.63-73.

Holtzclaw, E. V., Laddering: Unlocking the Potential of Consumer Behavior (2013), Wiley.

INCOSE, INCOSE Systems Engineering Handbook: A Guide for System Life Cycle Processes and Activities (2015), Wiley. 石井浩介, 飯野謙次, 価值づくり設計 (2008), 養賢堂.

Kamenetzky, M., The economics of the satisfaction of needs, Human Systems Management, Vol.2, No.2 (1981), pp.101-111.

Kmenta, S. and Ishii, K., Advanced FMEA using meta behavior modeling for concurrent design of products and controls, Proceedings of 1998 ASME DETC (1998).

Kobayashi, H., Strategic evolution of eco-products: a life cycle planning methodology, Research in Engineering Design, Vol.16, No.1-2 (2005), pp.1-16.

Kobayashi, H., Perspectives on sustainable product design methodology focused on local communities, Sustainability through Innovation in Product Life Cycle Design (2016), pp. 79-92, Springer.

Kobayashi, H. and Fukushige, S., A living-sphere approach for locally oriented sustainable design, Journal of Remanufacturing, Vo.8, No.3 (2018), pp.103-113.

Kobayashi, H., Sumimura, Y., Nguyen, D. C., Tran, M., Murata, H. and Fukushige, S., Need-based workshops for sustainable consumption and production in Vietnam, Proceedings of the 6th International Conference on Sustainable Design and Manufacturing (2019), pp. 35-47. 
丸岡吉人，ラダリング法のブランド戦略への適用，消費者行動研究，Vol.4, No.1 (1996), pp.25-39.

Max-Neef, M.A., Human Scale Development: Conception, Application and Further Reflections (1991), Apex Press.

水野滋, 赤尾洋二, 品質機能展開 (1978), 日科技連出版社.

西村秀和，藤倉俊幸，モデルに基づくシステムズエンジニアリング (2015)，日経 BP 社.

OECD, OECD Guidelines on Measuring Subjective Well-being (2013), OECD.

Otto, K. and Wood, K., Product Design (2000), Prentice Hall.

Paul, G. and Beitz, W., Engineering Design: A Systematic Approach (1988), Springer.

Pruitt, J. and Grudin, J., Personas: practice and theory, Proceedings of the 2003 conference on designing for user experiences (2003), pp.1-15.

Reynolds, T. J. and Olson, J. C., Understanding Consumer Decision Making (2001), Psychology Press.

Rosenman, M. A. and Gero, J.S., Purpose and function in design: from the socio-cultural to the techno-physical, Design Studies, Vol.19, No.2 (1998), pp.161-186.

佐藤嘉彦, テアダウンのすべて (1997), 日経 BP 社.

Sugita, Y., Fukushige, S. and Kobayashi, H., A visualization system of design information for locally-oriented sustainable product, Proceedings of the 24th CIRP Conference on Life Cycle Engineering, Vol.61 (2017), pp.617-622.

Sumimura, Y., Arai, S., Hung, D. P., Kobayashi, H., Murata, H. and Fukushige, S., Needs-based workshops in Vietnam and Japan for sustainable consumption and production, The 13th International Conference on EcoBalance (2018).

Ulrich, K. T. and Eppinger, S. D., Product Design and Development (1995), McGraw-Hill.

梅田靖, 木下裕介, 小島道一, 松本 光崇, SCP を指向した次世代ものづくり，日本 LCA 学会誌, Vol.15, No.2 (2019), pp.152-160.

Umeda, Y., Takata, S., Kimura, F., Tomiyaama, T., Sutherland, J., Kara, S., Herrmann, C. and Duflou, J., Toward integrated product and process life cycle planning - an environmental perspective, CIRP Annals - Manufacturing Technology, Vol.61, No.2 (2012), pp.681-702.

UN, Sustainable Development Goals (2015), available from < https://www.un.org/sustainabledevelopment/sustainabledevelopment-goals/>, (参照日 2019 年 10 月 9 日).

UNDP, Human Development Report (2015), UNDP.

UNEP, Global Outlook on Sustainable Consumption and Production Policies (2012), UNEP.

Vita, G., Hertwich, G. E., Stadler, K. and Wood, R., Connecting global emissions to fundamental human needs and their satisfaction, Environmental Research Letters, Vol.14, No.1 (2019), pp.1-16.

Weilkiens, T., Systems Engineering with SysML/UML (2007), Morgan Kaufmann.

\section{References}

Friedenthal, S., Moore, A. and Steiner, R., A Practical Guide to SysML (2012), Morgan Kaufmann.

Guillen-Royo, M., Sustainability and Wellbeing: Human-Scale Development in Practice (2015), Routledge.

Gutman, J., A Means-End chain model based on consumer categorization processes, Journal of Marketing, Vol.46, No.2 (1982), pp.60-72.

Hauser, J. and Clausing, D., The house of quality, Harvard Business Review, Vol.66, No.3 (1988), pp.63-73.

Holtzclaw, E. V., Laddering: Unlocking the Potential of Consumer Behavior (2013), Wiley.

INCOSE, INCOSE Systems Engineering Handbook: A Guide for System Life Cycle Processes and Activities (2015), Wiley.

Ishii, K. and Iino, K., Design for Manufacturability (2008), Yokendo (in Japanese).

Kamenetzky, M., The economics of the satisfaction of needs, Human Systems Management, Vol.2, No.2 (1981), pp.101-111.

Kmenta, S. and Ishii, K., Advanced FMEA using meta behavior modeling for concurrent design of products and controls, Proceedings of 1998 ASME DETC (1998).

Kobayashi, H., Strategic evolution of eco-products: a life cycle planning methodology, Research in Engineering Design, Vol.16, No.1-2 (2005), pp.1-16.

Kobayashi, H., Perspectives on sustainable product design methodology focused on local communities, Sustainability through Innovation in Product Life Cycle Design (2016), pp. 79-92, Springer.

Kobayashi, H. and Fukushige, S., A living-sphere approach for locally oriented sustainable design, Journal of Remanufacturing, Vol.8, No.3 (2018), pp.103-113.

Kobayashi, H., Sumimura, Y., Nguyen, D. C., Tran, M., Murata, H. and Fukushige, S., Need-based workshops for sustainable 
consumption and production in Vietnam, Proceedings of the 6th International Conference on Sustainable Design and Manufacturing (2019), pp. 35-47.

Maruoka, Y., Application of laddering method to brand strategy, Advances in Consumer Studies, Vol.4, No.1 (1996), pp.25-39 (in Japanese).

Max-Neef, M.A., Human Scale Development: Conception, Application and Further Reflections (1991), Apex Press.

Mizuno, S. and Akao, Y., Quality Function Deployment (1978), JUSE Press (in Japanese).

Nishimura, H. and Fujikura, T., Model-Based Systems Engineering (2015), Nikkei BP (in Japanese).

OECD, OECD Guidelines on Measuring Subjective Well-Being (2013), OECD.

Otto, K. and Wood, K., Product Design (2000), Prentice Hall.

Paul, G. and Beitz, W., Engineering Design: A Systematic Approach (1988), Springer.

Pruitt, J. and Grudin, J., Personas: practice and theory, Proceedings of the 2003 conference on designing for user experiences (2003), pp.1-15.

Reynolds, T. J. and Olson, J. C., Understanding Consumer Decision Making (2001), Psychology Press.

Rosenman, M. A. and Gero, J.S., Purpose and function in design: from the socio-cultural to the techno-physical, Design Studies, Vol.19, No.2 (1998), pp.161-186.

Sato, Y., Teardown (1997), Nikkei BP (in Japanese).

Sugita, Y., Fukushige, S. and Kobayashi, H., A visualization system of design information for locally-oriented sustainable product, Proceedings of the 24th CIRP Conference on Life Cycle Engineering, Vol.61 (2017), pp.617-622.

Sumimura, Y., Arai, S., Hung, D. P., Kobayashi, H., Murata, H. and Fukushige, S., Needs-based workshops in Vietnam and Japan for sustainable consumption and production, The 13th International Conference on EcoBalance (2018).

Ulrich, K. T. and Eppinger, S. D., Product Design and Development (1995), McGraw-Hill.

Umeda, Y., Kishita, Y., Kojima, M. and Matsumoto, M., Next generation manufacturing aiming at SCP, Journal of Life Cycle Assessment, Vol.15, No.2 (2019), pp.152-160 (in Japanese).

Umeda, Y., Takata, S., Kimura, F., Tomiyaama, T., Sutherland, J., Kara, S., Herrmann, C. and Duflou, J., Toward integrated product and process life cycle planning - an environmental perspective, CIRP Annals - Manufacturing Technology, Vol.61, No.2 (2012), pp.681-702.

UN, Sustainable Development Goals (2015), available from < https://www.un.org/sustainabledevelopment/sustainabledevelopment-goals/>, (accessed on 9 October, 2019).

UNDP, Human Development Report (2015), UNDP.

UNEP, Global Outlook on Sustainable Consumption and Production Policies (2012), UNEP.

Vita, G., Hertwich, G. E., Stadler, K. and Wood, R., Connecting global emissions to fundamental human needs and their satisfaction, Environmental Research Letters, Vol.14, No.1 (2019), pp.1-16.

Weilkiens, T., Systems Engineering with SysML/UML (2007), Morgan Kaufmann. 